\title{
Prosodic accommodation and salience: The nuclear contours of Andalusian Spanish speakers in Asturias
}

\author{
Aurora Troncoso-Ruiz ${ }^{1,2}$ and Gorka Elordieta ${ }^{3}$ \\ ${ }^{1}$ Center for Language Studies, Radboud University, Nijmegen \\ ${ }^{2}$ International Max Planck Research School for Language Sciences \\ ${ }^{3}$ University of the Basque Country UPV/EHU \\ m.troncosoruiz@let.ru.nl ORCID: 0000-0003-2718-2732 \\ gorka.elordieta@ehu.eus ORCID: 0000-0003-1235-6998
}

\begin{abstract}
Submitted: 17/10/2016. Accepted: 05/07/2017. Published online: 21/02/2018
Citation / Cómo citar este artículo: Troncoso-Ruiz, A. and Elordieta, G. (2017). Prosodic accommodation and salience: The nuclear contours of Andalusian Spanish speakers in Asturias. Loquens, 4(2), e043. doi: http://dx.doi.org/10.3989/loquens.2017.043
\end{abstract}

\begin{abstract}
This study investigates the convergent accommodating behaviour of Andalusian speakers (Southern Spain) relocated in Asturias (Northern Spain), a context of dialect contact, in terms of intonation. We aim to address three research questions: (1) is there evidence for accommodation? (2) Do social factors determine accommodation? And (3) does salience predict which prosodic features are more likely to be adopted by relocated speakers? We elaborated a corpus of spontaneous speech including an experimental group of Andalusian speakers in Asturias and two control groups of Asturian and Andalusian people. The relocated Andalusians were interviewed by a speaker of Andalusian Spanish and a speaker of Amestáu (hybrid variety between Asturian and Spanish), and their intonation patterns were compared to the ones found in the control populations. During the interviews, we also gathered data about how integrated these relocated speakers were in Asturias. We found that all participants show a tendency towards convergent accommodation to the Amestáu interlocutor, producing late falling pitch contours in nuclear position in declaratives and final falling contours in absolute interrogatives. The most integrated speakers in the Asturian community are the ones showing more features of the varieties spoken in the area. Finally, the most salient features to an Andalusian ear - the presence of final falls in Asturian, Asturian Spanish and Amestáu absolute interrogatives as opposed to final rises in Andalusian and Standard Peninsular Spanish - were the ones showing the highest percentages of adoption in relocated speakers. We could conclude, then, that the most salient prosodic features are acquired more easily by the most integrated relocated speakers.
\end{abstract}

Keywords: accommodation; prosody; dialectal contact; Andalusian Spanish; Asturian Spanish; salience.

RESUMEN: Acomodación prosódica y prominencia: Los contornos nucleares de hablantes andaluces de castellano en Asturias.-Este estudio investiga acomodación convergente en hablantes de castellano de Andalucía que se han mudado a Asturias, un contexto de contacto de dialectos, en términos prosódicos. Abordamos tres preguntas de investigación: 1) ¿existen evidencias de acomodación en estos hablantes?; 2) ¿está determinado el comportamiento acomodante por factores sociales?, y 3 ) ¿puede la prominencia predecir qué rasgos prosódicos adoptarán los hablantes reubicados? Hemos elaborado un corpus de habla espontánea que incluye un grupo de hablantes andaluces reubicados en Asturias y dos grupos de control de hablantes asturianos y andaluces. Las hablantes reubicadas fueron entrevistadas por una interlocutora hablante de amestáu (variante híbrida de asturiano y español) y por una andaluza, y sus patrones entonativos fueron comparados a los de las poblaciones de control. Durante las entrevistas, también recogimos datos sobre cómo de integradas estaban en Asturias. Todas las hablantes reubicadas mostraron una tendencia a acomodar de forma convergente a la interlocutora, retrasando el movimiento descendente de tono a la posición nuclear en las oraciones declarativas y usando tonos descendentes en las interrogativas absolutas. Las hablantes más integradas en la comunidad asturiana son las que muestran más rasgos de las variedades habladas en esa zona. Finalmente, los rasgos más prominentes al oído andaluz - la presencia de descensos finales en interrogativas absolutas en asturiano, amestáu y el castellano de Asturias, diferentes de las subidas finales en el castellano peninsular y andaluz - fueron los rasgos con los porcentajes más altos de adopción en hablantes reubicadas. Podríamos concluir, entonces, que las hablantes reubicadas adquieren con más facilidad los rasgos prosódicos más prominentes.

Palabras clave: acomodación; prosodia; contacto dialectal; andaluz; asturiano, prominencia. 


\section{INTRODUCTION}

The transfer of linguistic features - either syntactic, morphological, lexical, phonetic, or phonological-has been empirically attested to take place between different languages and/or dialects when they come into contact. Although most of the work on linguistic contact deals with a speaker's native features being transferred into their second language (L2), the opposite direction has also been confirmed, i.e., speakers can adopt in their first language (L1) the features of a language or dialect they are in contact with. This latter type of linguistic transfer, from the native language or dialect to a second language or dialect, can take place in different social settings, such as bilingual communities (see Colantoni \& Gurlekian, 2004; Elordieta, 2003, 2006; Elordieta \& Calleja, 2005; Elordieta \& Irurtzun, 2012, 2016; Elordieta \& Romera, in press; Mennen, 2004, 2015; Muntendam \& Torreira, 2016; O’Rourke, 2005; Romera \& Elordieta, 2013; Simonet, 2008, 2011; among others). As Romera and Elordieta (2013) argue, most of the purported cases of adoption of L2 features in L1 are cases of what they call indirect transfer. This situation arises when two dialects of a language are in contact, and one of the dialects is spoken by native speakers of another language and is heavily influenced by it. In their study, Romera and Elordieta claim that native speakers of Peninsular Spanish do not adopt features of Majorcan Catalan directly, but only through the variety of Spanish spoken by native speakers of Majorcan Catalan.

This study deals with a particular situation of language contact involving relocated populations, i.e., adult speakers of a given language variety move to a different region and, therefore, they live in contact with another language or a new variety of their native language. The hypothesis is that this contact has an effect on the way the relocated populations speak, as they may converge towards the features of the new language or dialect. The subjacent mechanism underlying this phenomenon of language convergence is commonly known as accommodation. This concept was proposed by Giles (1973) in the framework of social psychology within Communication Accommodation Theory (CAT), and was then adapted to linguistic studies (among others, Giles \& Ogay, 2007). In this theory, accommodation is described as a speaker's ability to modify their linguistic patterns in order to adjust them to their interlocutor's speech. This behaviour can follow two directions. On the one hand, divergent accommodation consists in speakers accentuating the features that characterize their native variety with the aim of highlighting their distinctiveness and amounting to linguistic diversification. On the other hand, in convergent accommodation, speakers alter their native features in order to resemble those found in the interlocutor's speech. This latter type of accommodation contributes to the increase of similarities between the varieties involved.

Trudgill's (1986) study of relocated British and American English speakers is a pioneer and extensive account of long-term convergent accommodation. Romera and
Elordieta's (2013) account of Peninsular Spanish speakers relocated in the Catalan-speaking island of Majorca constitutes the only work on convergent accommodation by relocated speakers in a Spanish setting. Convergent accommodation has also been attested for momentary situations as short-term accommodation, such as customertravel agent conversation (Giles, Coupland, \& Coupland, 1991), telephone conversations (De Looze, Scherer, Vaughan, \& Campbell, 2014), experimental tasks (Pardo, 2006, 2013), experimental interactions (MacLeod, 2012), or exposure to formal contexts (Hernández-Campoy, 2010).

The present study investigates a situation of dialect contact between two varieties of Peninsular Spanish, such as Andalusian and Asturian Spanish. Specifically, it focuses on western Andalusian Spanish speakers, from the province of Cádiz, relocated to the northern Spanish region of Asturias. The Principality of Asturias, located in the Northwest of the Iberian Peninsula, is characterized by the presence of two Romance languages: Spanish and Asturian (also known as Bable). Only Spanish has an official status. The Asturian Language Academy (Academia de la Llingua Asturiana) carried out the standardization of Asturian during the eighties. There are three varieties of Asturian in this region: Eastern, Western, and Central. The latter is considered the standard variety, and it is the variety spoken in the most populated urban nuclei, Oviedo and Gijón. Nowadays, the use, transmission, and promotion of Asturian are legally protected. However, Asturian is not recognized as an official language by the Spanish government. As a consequence, Asturian society reflects a situation of diglossia, where Spanish and Asturian are used in different contexts.

This diglossic situation has a clear effect on the number of native speakers of Asturian. According to statistical studies carried out by Llera Ramo (1994) and Llera Ramo and San Martín Antuña (2002), the percentage of L1 Asturian speakers has decreased from $36 \%$ in 1991 to $16 \%$ in 2002 (100,000 speakers, according to Ethnologue; Lewis, Simons, \& Fennig, 2015), and Asturian is in fact considered an endangered language by UNESCO. Nevertheless, there has been an increase in the number of bilingual speakers of Spanish and Asturian, that is, L2 Asturian speakers (from $5.8 \%$ in 1991 to $20 \%$ in 2002, or 450,000 speakers; see Ethnologue, 2015). Bilingual speakers shift from one language to another rather easily, even in the same conversation, sometimes depending on the register required by the situation (Muñiz Cachón, 2002-2003). This pattern of intense language contact has led to the emergence of a new linguistic variety in which Spanish and Asturian come together: Amestáu (d'Andrés Díaz, 1998). The literature on the linguistic situation in Asturias distinguishes two views of what Amestáu should refer to, depending on which variety is considered to be the baseline of this mixture. Amestáu can be considered a variety of Spanish with linguistic features from Asturian, or a variety of Asturian with linguistic features from Spanish (Muñiz Cachón, 2002-2003). However, as suggested by Muñiz Cachón (2002-2003), it should be noted that many 
of the dialectal characteristics that arise in Amestáu as spoken by Spanish-Asturian bilinguals seem to be also present in the variety of Spanish spoken by monolingual speakers, a variety that may be called Asturian Spanish. Thus, the boundaries between Amestáu and Asturian Spanish are not clear to many researchers. For the purpose of this study, we consider Amestáu a variety where both Spanish and Asturian converge, without taking into account which of the two languages is the base one.

Some morphosyntactic differences between Asturian or Amestáu and standard Peninsular Spanish could include the co-occurrence of a determiner and a possessive in DPs (see 1a and 1b) and the existence of postverbal clitics (i.e., enclitics) in finite verbs (see 2), among other aspects:

(1) a. La mio hermana (Asturian)

b. La mi hermana (Amestáu)

c. Mi hermana (Peninsular Spanish) 'My sister'

(2) a. Díxome güei que va venir mañana (Asturian)

b. Díjome hoy que va venir mañana (Amestáu)

c. Me ha dicho hoy que va a venir mañana (Peninsular Spanish)

'He/she has told me today he/she is coming tomorrow'

There are differences in verbal inflection and morphology between Asturian or Amestáu and standard Peninsular Spanish, such as the lack of perfect tenses in Asturian/Amestáu. In nominal inflection, the masculine singular $u$ of Asturian/Amestáu contrasts with Peninsular Spanish $o$. Feminine plural in Asturian/Amestáu is es, whereas in Peninsular Spanish it is as. Regarding the lexicon, a huge amount of borrowings from Asturian (e.g., mancar 'to hurt'; prestar 'to please'; guah.e 'boy') have been fully incorporated to Asturian Spanish.

The phonology of Asturian has been widely studied at prosodic and segmental levels (cf. Alvarellos Pedrero, Muñiz Cachón, Díaz Gómez, \& González Rodríguez, 2011; Canellada, 1984; Cuevas Alonso \& López Bobo, 2010; Cuevas Alonso, López Bobo, Arias-Cachero Cabal, \& Bleorţu, 2012; Díaz Gómez, Muñiz Cachón, López Bobo, González Rodríguez, \& Cuevas Alonso, 2007; López Bobo, Cuevas Alonso, Díaz Gómez, \& Viejo Lucio-Villegas, 2008a, 2008b; López Bobo, González Rodríguez, Cuevas Alonso, Díaz Gómez, \& Muñiz Cachón, 2005; Muñiz Cachón, 2013; Muñiz Cachón \& Alvarellos Pedrero, 2008; Muñiz Cachón, González Rodríguez, Díaz Gómez, \& Alvarellos Pedrero, 2006-2007-2008), but very few empirical studies focus on the influence of the Asturian language on the variety of Spanish spoken in the region or vice versa.

As regards the variety of Spanish spoken in Andalusia, it is considered to diverge from Castilian Spanish and other Peninsular varieties. Authors such as Carbonero, Álvarez, Casas, and Gutiérrez (1992), García-Amaya (2008), Gil Fernández (2000), Hualde (2005, 2013), Henriksen and García-Amaya (2012), Narbona, Cano, and Morillo (1998), or Navarro Tomás (1991), to cite a few, have contributed to the vast literature on Andalusian Spanish by reporting its linguistic features. Two major dialectal groups (Eastern and Western) can be distinguished in Andalusian Spanish, based on the different distribution of linguistic features (Caja, 1977; García Mouton, 1992; Narbona, Cano, \& Morillo, 1998). For instance, consider the difference in the use of the second person plural pronoun in (3), between ustedes in Western Andalusian Spanish and vosotros in Eastern Andalusian Spanish:

(3) ¿Ustedes os vais a ir? (Western Andalusian Spanish)

¿Vosotros os vais a ir? (Eastern Andalusian and Peninsular Spanish)

'Are you going to leave?'

The main differences between Western and Eastern Andalusian dialects are phonological. These aspects, described in linguistic atlases (Alvar, 1959; García Mouton, 1992), include the neutralization of standard or Castilian Spanish /s/ and / $\theta /$ into / $\theta /$ (known as 'ceceo') in Western Andalusian Spanish and into /s/ ('seseo') in Eastern varieties (García-Amaya, 2008; Hualde, 2013; Mondéjar, 2001, among others), or the presence of vowel opening in plural nouns and adjectives in Eastern dialects (Zamora Vicente, 1967). This study will only involve the Western variety, as all of the speakers that participated in the study were born and raised in cities and towns in the province of Cádiz, in Western Andalusia.

The main objective of the present work is to observe whether native speakers of Andalusian Spanish relocated for socio-economic reasons to Asturias show any degree of accommodation (divergent or convergent) to the language varieties spoken in Asturias, namely Asturian, Amestáu, and Asturian Spanish. Although Andalusia and Asturias are geographically distant areas, social mobility between these two communities has been constant. Apart from the significant number of Andalusians who emigrated to Asturias in the sixties and seventies of the twentieth century, in the present century an average of 500 natives of Andalusia have emigrated to Asturias every year (Sociedad Asturiana de Estudios Económicos e Industriales, 2017, available data from 2001 until 2015). This mobility provides us with a specific setting in which the varieties spoken in those regions come into contact. The focus is on the Asturian cities of Oviedo and Gijón, as these urban nuclei receive more than half of the population migrating to Asturias: $33.04 \%$ and $27.82 \%$, respectively. We assume that Andalusian Spanish immigrants relocated in Asturias are in contact with Asturian Spanish and/or with Amestáu rather than with Asturian. Although the contact situation between Asturian and Spanish is the source of Amestáu, the percentage of native Asturian speakers is rather low nowadays, as we described above (16\%; see Llera Ramo \& San Martín Antuña, 2002), and the percentage of L1 Asturian speakers in urban nuclei is very low (Llera Ramo \& San Martín Antuña, 2002). ${ }^{1}$ Thus, it is reasonable to assume that Andalusian speakers will be 
more in contact with Asturian Spanish and Amestáu speakers than with L1 Asturian speakers.

Furthermore, in order to contribute to the study of what social factors modulate accommodation, we identify the role that social factors play in the variability found among speakers, in particular, the degree of social integration in the new community. Following Romera and Elordieta (2013) and Giles, Coupland and Coupland (1991), our hypothesis is that the most socially integrated speakers will display a higher degree of adoption of features from the varieties that they are in contact with.

Finally, we also investigate why some variables are more readily subject to accommodation. There is a substantial amount of work suggesting that perceptual salience determines which linguistic features are more likely to be acquired (Auer, Barden, \& Grosskopf, 1998; Graff, Labov, \& Harris, 1986; Fridland, Bartlett, \& Kreuz, 2004; MacLeod, 2012; Schirmunski, 1930; Trudgill, 1986; van Bezooijen \& Gooskens, 1999). Our hypothesis is that the features of Asturian Spanish or Amestáu that are more salient to an Andalusian speaker will be acquired or adopted more easily. In other words, if speakers do converge to the varieties spoken in Asturias, diverging from their native dialect, the more salient the feature is, the more likely it will be used by the relocated speaker.

\section{METHODOLOGY}

Our corpus was obtained through recordings of spontaneous conversations with three different types of speakers: (1) the experimental group of Andalusian speakers who have emigrated to Asturias, (2) a control group of Asturian Spanish and Amestáu speakers, and (3) a second control group of nonrelocated Andalusian speakers. Other data elicitation methods such as Discourse Completion Task (DCT) or reading tasks are more practical in terms of allowing the corpus to be analyzed faster and allowing for more control over the stimuli used. However, we sacrificed functionality over naturalness, as we consider accommodation to be a spontaneous phenomenon. Taking into account the studies by Romera and Elordieta (2013) the idea was that unscripted conversations would provide a suitable context for natural accommodating behaviour to take place (see below for a more extended explanation of the data elicitation procedure).

\subsection{Participants}

\subsubsection{Experimental group: Relocated Andalusians}

We recorded 4 relocated Andalusian speakers, all young women (19-28 years old), who had been born and raised in the Southwestern area of Andalusia (in towns of the province of Cádiz), and were consequently speakers of the Western Andalusian variety of Spanish. They were recruited through colleagues, friends, and Facebook groups for Andalusians in Asturias. Therefore, the sample was not as homogeneous as we would have expected in an ideal world. The four of them had moved to the Central region of Asturias - Oviedo (speakers 1, 2, and 3) and Gijón (speaker 4) - , which, as mentioned in Section 1, are the cities that received more immigrants from other areas of Spain. Both of these cities belong to the area where Central Asturian is spoken. All of the participants had experienced university education and had been living in these Asturian urban nuclei for a short period of time (1-5 years). Table 1 contains the relevant information for each experimental subject.

\subsubsection{Control populations}

The main intonational features of the relocated speakers had to be compared with the main intonational features of the native variety of Spanish of these speakers, to observe which aspects are maintained and which are changed. Also, a comparison was made between the intonational patterns of the relocated speakers and those of the linguistic varieties these speakers are in contact with, i.e., Asturian Spanish and Amestáu.

The first step was to turn to the descriptions in previous literature. As regards the native variety of the relocated speakers, Henriksen and García-Amaya (2012) elaborated a detailed description of Jerezano, the variety spoken in one of the most populated cities of Southwestern Andalusia: Jerez de la Frontera. Their corpus was gathered with the Discourse Completion Task method, using a questionnaire based on Prieto and Roseano (2010). On the other hand, Asturian had been described in Alvarellos Pedrero et al. (2011), Cuevas Alonso and López Bobo (2010), Cuevas Alonso et al. (2012), Díaz Gómez et al. (2007), López Bobo et al. (2005, 2008a, 2008b), Muñiz Cachón (2013), Muñiz Cachón and Alvarellos Pedrero (2008), and Muñiz Cachón et al. (2006-2007-2008), among others. All of these studies followed a reading task methodology where speakers had to read declarative and absolute interrogative utterances, always with the surface linear order SubjectVerb-Object (Romano, Lai, \& Roullet, 2005). ${ }^{2}$

There are two reasons why our study on prosodic accommodation cannot be based solely on the previous literature on Asturian intonation. First, we do not consider Asturian to be the language in direct contact with the Spanish variety of the newcomers (because of the low percentage of current L1 Asturian speakers, among other reasons; see Section 1). Rather, the present study considers Amestáu and Asturian Spanish to be the linguistic varieties that newcomers will be in contact with. Unfortu-

\footnotetext{
1 According to Llera Ramo and San Martín Antuña (2002), 17.2\% of the population of Central Asturias was raised with Asturian as L1.

2 This Subject-Verb-Object is maintained also in interrogative sentences, which is not the unmarked word order for information seeking interrogatives.
} 
Table 1: Profiles of the experimental subjects.

\begin{tabular}{|c|c|c|c|c|c|c|}
\hline & Sex & Age & Place of Birth & $\begin{array}{c}\text { Years in } \\
\text { Asturias }\end{array}$ & $\begin{array}{c}\text { University } \\
\text { Studies }\end{array}$ & Occupation \\
\hline Speaker 1 & Female & 28 & San Roque & 1 & Yes & Unemployed \\
\hline Speaker 2 & Female & 26 & Casares & 2 & Yes & Unemployed \\
\hline Speaker 3 & Female & 19 & Jerez de la Frontera & 5 & Yes & Student \\
\hline Speaker 4 & Female & 27 & Cádiz & 1 & Yes & Employed \\
\hline
\end{tabular}

nately, most of the intonational work done in Asturias focuses only on Asturian, leaving aside Amestáu or Asturian Spanish. Furthermore, the methodology used in the studies concerning varieties spoken in Asturias is based on a reading task, in which speakers had to read aloud a series of sentences. As stated above, studies of accommodation and of the role of social factors in the different degrees of accommodation observed among speakers need to be based on conversations or interviews with speakers, and hence the corpus must be based on spontaneous speech rather than on read speech.

Thus, we conducted and recorded interviews with 2 speakers of Améstau and 4 speakers of Asturian Spanish. The criterion used to determine whether a person was a speaker of Asturian Spanish or Amestáu was based on the vocabulary (i.e., lexical expressions) used and the morphological and syntactic features of their speech. They all matched the Andalusian speakers' socio-economic characteristics, as they were young (under 30 years old) and had university experience.

The existing study on Southwestern Andalusian Spanish intonation (Henriksen \& García-Amaya, 2012) was not based on spontaneous speech either. Hence, in order to establish a fair comparison between the intonation of relocated Andalusian speakers and Andalusian speakers in origin (i.e., in Andalusia), we recorded two Southwestern Spanish speakers engaging in spontaneous speech. They were two young ( 20 and 22 years old) females studying a university degree. Both of them had been born in Jerez de la Frontera and had always lived there, not having been exposed to other varieties of Spanish.

\subsection{Data elicitation}

The group of relocated speakers were asked to engage in a 20-40-minute-long conversation with two different interlocutors, one of them a speaker of Amestáu and the other one a speaker of Andalusian Spanish. A 23-year-old female speaker of Amestáu (henceforth, the Amestáu interlocutor) always conducted the first interview, based on the topic of feminism. This topic was chosen with the idea of making the female subject feel more comfortable and perhaps even feel more empathy towards the female interviewer. The second interview was conducted by an Andalusian speaker, who asked the subjects questions about their view on Asturias and the local community, their lives there, and their attitudes towards the host com- munity (i.e., Asturias, Asturian people, and speakers of Amestáu and Asturian Spanish) and towards their own community (i.e., Andalusia, Andalusian people, Andalusians in Asturias). With this interview we intended to obtain information about the subjects' degree of social integration in the host community, Asturias. The interviewer had to be a member of the community, that is, a native Andalusian, in order to make the subjects' feel comfortable about expressing their views and opinions on the host community and their own community. The first author of this study, herself a native speaker of Western Andalusian Spanish, was the interviewer.

The 4 relocated Andalusian subjects of our study were encouraged to answer questions from the interviewer, but also to ask questions to the interviewer, based on the methodology of two-way interviews used in Romera and Elordieta (2013) and Elordieta and Romera (in press). The participants were never provided with a written list of what they had to answer or ask, but rather followed the topics proposed by the interlocutors. We expected the speakers to spontaneously ask questions, encouraged by their own curiosity and involvement in the conversation. With this methodology, at least 10 declarative utterances, 10 absolute interrogatives, and 10 wh-interrogatives could be obtained from each interview.

For the recording of the control groups, the interviews had two different parts. First, both speakers engaged in a spontaneous conversation. A list of possible topics (e.g., bullfighting) was provided to foster fluency in the conversation. Afterwards, we decided to include a role play, where participants were asked to pretend to be looking for an apartment, a room, or a housemate. With both tasks, we wanted to make sure we obtained a significant number of declarative and interrogative (absolute and whquestions) utterances from each control subject.

All the conversations were recorded in the Phonetics Laboratory of the Faculty of Arts at the University of Oviedo, Asturias. A Tascam DR100 digital recorder with an in-built omnidirectional microphone was used to capture the voice of the Andalusian participants and the interviewers. Over 8 hours of conversation were recorded in WAV format, sampled at 44,100 $\mathrm{Hz}$ and 16 bits.

\subsection{Measurements}

The prosodic analysis of the corpus obtained was carried out using the Sp_ToBI system of tone labeling for 
intonation in Spanish, based on the Autosegmental-Metrical model of intonational analysis first developed by Pierrehumbert (1980), Beckman and Pierrehumbert (1986), and Pierrehumbert and Beckman (1988; see Ladd, 2008, for an overview). The original proposal of Sp_ToBI was due to Beckman, Díaz-Campos, McGory, and Morgan (2002), and it has undergone a series of revisions by Estebas Vilaplana and Prieto Vives (2008), Face (2008), Prieto and Roseano (2010), and Hualde and Prieto (2015), among others. In this system, there are two types of tonal events in the signal (movements in $f$ ) that are identified and labeled: pitch accents and boundary tones. Pitch accents are generally associated to stressed syllables, with a distinction between nuclear and prenuclear pitch accents. A nuclear pitch accent is usually the rightmost accent in an Intonational Phrase, and prenuclear pitch accents are the accents preceding the nuclear accent. Boundary tones occur at the edges of prosodic constituents, most often at higher levels of the prosodic hierarchy (Intermediate and Intonational Phrases, in $\mathrm{Sp} \mathrm{ToBI}$ ).

The Sp_ToBI model has been widely applied to the description of the intonation of Spanish varieties (see Hualde \& Prieto, 2015; Prieto \& Roseano, 2010), all in nonspontaneous speech. Andalusian Spanish is one of the varieties analyzed with this system (see Henriksen \& García-Amaya, 2012). The intonation of Asturian and Asturian Spanish has not been investigated with $\mathrm{Sp}$ ToBI, but the description of pitch movements in lexical accents by Alvarellos Pedrero et al. (2011) has been adapted to Sp_ToBi conventions for the purpose of the comparison with Andalusian Spanish.

Thanks to the two-way interviews, we could extract declarative, wh-interrogative, and absolute interrogative sentences from the recordings of the speakers. We adopted the criterion of having utterances that were as comparable as possible. Knowing that information structure and marked pragmatic meanings are manifested intonationally, we selected utterances that were "neutral" informationally and pragmatically. For declaratives, we selected utterances that provided given and new information, but without constituents that conveyed narrow focus in an obvious way. As for interrogatives, we selected utterances that sought information from the interlocutor, discarding marked interrogatives such as echo questions or confirmation-seeking questions. Using the software for phonetic analysis Praat (version 6.0.31), we annotated manually prenuclear accents, nuclear accents, and boundary tones of all the sentences in the corpus. We then compared the patterns found in the relocated speakers to those in the control populations (Amestáu and Asturian Spanish on the one hand and Andalusian Spanish on the other) to determine to what degree the experimental subjects were showing evidence for convergent accommodation towards the Amestáu interlocutor. We also studied the soci- olinguistic interviews in order to identify how integrated and satisfied the relocated speakers were in Asturias.

\section{RESULTS}

As previously stated in Section 2, we annotated the sentences extracted from the relocated speakers and compared their prosodic patterns to those found in control populations groups and the previous literature for Andalusian, Asturian Spanish, and Amestáu. When we mention Andalusian Spanish, we are referring only to the variety of Andalusian Spanish relevant for this study, namely Jerezano Spanish (see Section 2.1.2). When referring to the varieties spoken in Asturias, we always refer to those spoken in the Central region of Asturias. In this article we will concentrate on nuclear contours (i.e., the sequences formed by a nuclear accent and a boundary tone), where the main differences between varieties are found. Prenuclear regions are more similar (see 3.1). As a reference, Table 2 summarizes the most frequent nuclear accents and boundary tones found in declarative and absolute interrogative utterances for these control varieties. ${ }^{3}$

Tables 3 and 4 contain the relative frequencies of the nuclear contours represented in Table 2, for the control Amestáu and Asturian Spanish speakers, and the control Andalusian speakers, respectively, in declarative and absolute interrogatives. The tables also indicate the number of utterances of each type of sentence for each speaker.

\subsection{Declaratives}

As regards declarative sentences, the varieties spoken in Asturias and also Andalusian Spanish display rising accents with a posttonic peak $\left(\mathrm{L}+<\mathrm{H}^{*}\right)$ in prenuclear position. Therefore, the main difference between Andalusian Spanish and the varieties spoken in Asturias is found in the nuclear accent position (i.e., last pitch accent). The nuclear accent in Andalusian Spanish declaratives is a valley that extends throughout the boundary tone $\left(\mathrm{L}^{*} \mathrm{~L} \%\right.$; see Henriksen \& García-Amaya, 2012, and Figure 1). Asturian, Asturian Spanish, and Amestáu declaratives, on the other hand, display a falling nuclear accent followed by a low boundary tone $(\mathrm{H}+\mathrm{L} * \mathrm{~L} \%)$, according to Alvarellos Pedrero et al. (2011) and the Amestáu and Asturian Spanish spontaneous speech corpus (Figure 2).

Table 5 summarizes the frequency of appearance of the falling nuclear contour $\mathrm{H}+\mathrm{L}^{*} \mathrm{~L} \%$ (typical of Amestáu and Asturian Spanish) in the speech of the relocated Andalusians during the two interviews (with the Andalusian and the Amestáu interlocutors). In general, all speakers show a general tendency towards an increase in the occurrence of $\mathrm{H}+\mathrm{L}^{*} \mathrm{~L} \%$ when in conversation with the

\footnotetext{
3 Analyzing the performance of the Amestáu interlocutor, we found no evidence of accommodating behaviour toward Andalusian Spanish, i.e., her contours fall into the Asturian Spanish and Améstau configurations. This may due to the fact that this interlocutor was instructed to maintain her dialect features throughout all the interviews.
} 
Table 2: Nuclear accents and boundary tones in the control varieties (Andalusian Spanish, Amestáu, and Asturian Spanish).

\begin{tabular}{|l|l|l|l|}
\hline & \multicolumn{1}{|c|}{ Variety } & \multicolumn{1}{c|}{ Nuclear Accent } & \multicolumn{1}{c|}{ Boundary Tone } \\
\hline \multirow{3}{*}{ Declaratives } & Andalusian Spanish & $\mathrm{L}^{*}$ & $\mathrm{~L} \%$ \\
\cline { 2 - 4 } & Amestáu and Asturian Spanish & $\mathrm{H}+\mathrm{L}^{*}$ & $\mathrm{~L} \%$ \\
\hline \multirow{2}{*}{ Abs. Interrog. } & Andalusian Spanish & $\mathrm{L} * / \mathrm{L}+\mathrm{H}^{*}$ & $\mathrm{H} \%$ \\
\cline { 2 - 4 } & Amestáu and Asturian Spanish & $\mathrm{H}+\mathrm{L}^{*} / \mathrm{H}^{*}$ & $(\mathrm{H}) \mathrm{L} \%$ \\
\hline
\end{tabular}

Table 3: Frequency of occurrence of $\mathrm{H}+\mathrm{L} * \mathrm{~L} \%$ in declarative utterances and $\mathrm{H}+\mathrm{L} *(\mathrm{H}) \%$ or $\mathrm{H}^{*}(\mathrm{H}) \mathrm{L} \%$ in absolute interrogative utterances by the control Amestáu and Asturian Spanish speakers ( $\mathrm{S}=$ Speaker; $N=$ number of utterances).

\begin{tabular}{|c|c|c|c|c|}
\hline & $\begin{array}{c}\boldsymbol{N} \\
\text { Declaratives }\end{array}$ & $\begin{array}{c}\text { Frequency } \\
\mathbf{H}+\mathbf{L} * \mathbf{L} \%\end{array}$ & $\begin{array}{c}\boldsymbol{N} \\
\text { Absolute } \\
\text { interrogatives }\end{array}$ & $\begin{array}{c}\text { Frequency } \\
\mathbf{H}+\mathbf{L}^{*} \mathbf{L} \% \\
\mathbf{H} * \mathbf{H}) \mathbf{L} \%\end{array}$ \\
\hline Amestáu S1 & 25 & $84 \%$ & 18 & $100 \%$ \\
\hline Amestáu S2 & 19 & $94.73 \%$ & 7 & $100 \%$ \\
\hline Asturian Spanish S1 & 12 & $92 \%$ & 20 & $100 \%$ \\
\hline Asturian Spanish S2 & 16 & $81.25 \%$ & 13 & $100 \%$ \\
\hline Asturian Spanish S3 & 18 & $94.40 \%$ & 17 & $94.11 \%$ \\
\hline Asturian Spanish S4 & 19 & $78.90 \%$ & 14 & $100 \%$ \\
\hline
\end{tabular}

Table 4: Frequency of occurrence of $\mathrm{L}^{*} \mathrm{~L} \%$ in declarative utterances and $\mathrm{L}^{*} \mathrm{H} \%$ or $\mathrm{L}+\mathrm{H}^{*} \mathrm{H} \%$ in absolute interrogative utterances by the control Andalusian speakers ( $\mathrm{S}=$ Speaker; $N=$ number of utterances).

\begin{tabular}{|c|c|c|c|c|}
\hline & $\begin{array}{c}\boldsymbol{N} \\
\text { Declaratives }\end{array}$ & Frequency L* L\% & $\begin{array}{c}\boldsymbol{N} \\
\text { Absolute } \\
\text { interrogatives }\end{array}$ & $\begin{array}{c}\text { Frequency } \\
\mathbf{L} * \mathbf{H} \% \\
\mathbf{L}+\mathbf{H}^{*} \mathbf{H} \%\end{array}$ \\
\hline Andalusian S1 & 11 & $81.82 \%$ & 10 & $100 \%$ \\
\hline Andalusian S2 & 10 & $80 \%$ & 14 & $92.86 \%$ \\
\hline
\end{tabular}

Amestáu interlocutor (Figure 3). All speakers taken together, the difference is statistically significant $\left(\chi^{2}=5.636\right.$, $p=.018)$.

\subsection{Absolute interrogatives}

The final contour of absolute interrogatives is significantly different in Andalusian Spanish compared to Amestáu and Asturian Spanish. Henriksen and GarcíaAmaya (2012) describe the most prototypical contour in Western Andalusian Spanish as a valley followed by a high rising boundary tone $\left(\mathrm{L}^{*} \mathrm{HH} \%\right.$, in their analysis, as opposed to regular rising boundary tone, $\mathrm{H} \%$ ). Apart from this contour, in our corpus corresponding to the control group of Western Andalusian speakers we also found a rise in the nuclear accent that continues through the boundary tone $\left(\mathrm{L}+\mathrm{H}^{*} \mathrm{H} \%\right)$. In our analysis, we established a distinction between $\mathrm{H} \%$, upstepped ${ }_{i} \mathrm{H} \%$, downstepped $! \mathrm{H} \%$, and $\mathrm{H} \%$ taking into account the degree in which the speaker's pitch level rises from the end of the tonic syllable through the boundary tone. Rises over
$100 \mathrm{~Hz}$ between the end of the tonic syllable and the final syllable were labeled as $i \mathrm{H} \%$, and those under that level as $\mathrm{H} \%$. In ! $\mathrm{H} \%$, the pitch level of the nuclear accent is sustained throughout the final syllable. Nevertheless, future research is required in order to confirm whether this tripartite distinction is a matter of phonetic variation or of phonological contrast. The latter would be proven if the differences in pitch range of the final rise were associated to a difference in pragmatic meaning for Andalusian Spanish speakers. For the sake of a clearer presentation, we will group all these configurations under the label $\mathrm{H} \%$ (cf. Table 4). Figure 4 illustrates a final rising contour in Andalusian Spanish in our corpus.

On the other hand, Asturian Spanish and Amestáu show a pitch movement during the final contour of absolute interrogatives that contrasts radically with most Spanish varieties. In Amestáu and in Asturian Spanish, the final contour displays a high tone followed by a falling tone, which can start either on the nuclear accent or later in the boundary tone $\left(\mathrm{H}+\mathrm{L} * \mathrm{~L} \%\right.$ and $\mathrm{H}^{*}(\mathrm{H}) \mathrm{L} \%$, respectively). Alvarellos Pedrero et al. (2011) also note that Asturian lacks rising boundary tones, and it seems reasonable to presume that 
Figure 1: Waveform and $f_{0}$ curve of the declarative sentence for Andalusian Spanish Yo estoy estudiando derecho ('I am studying law') from the control corpus of Andalusian speakers.

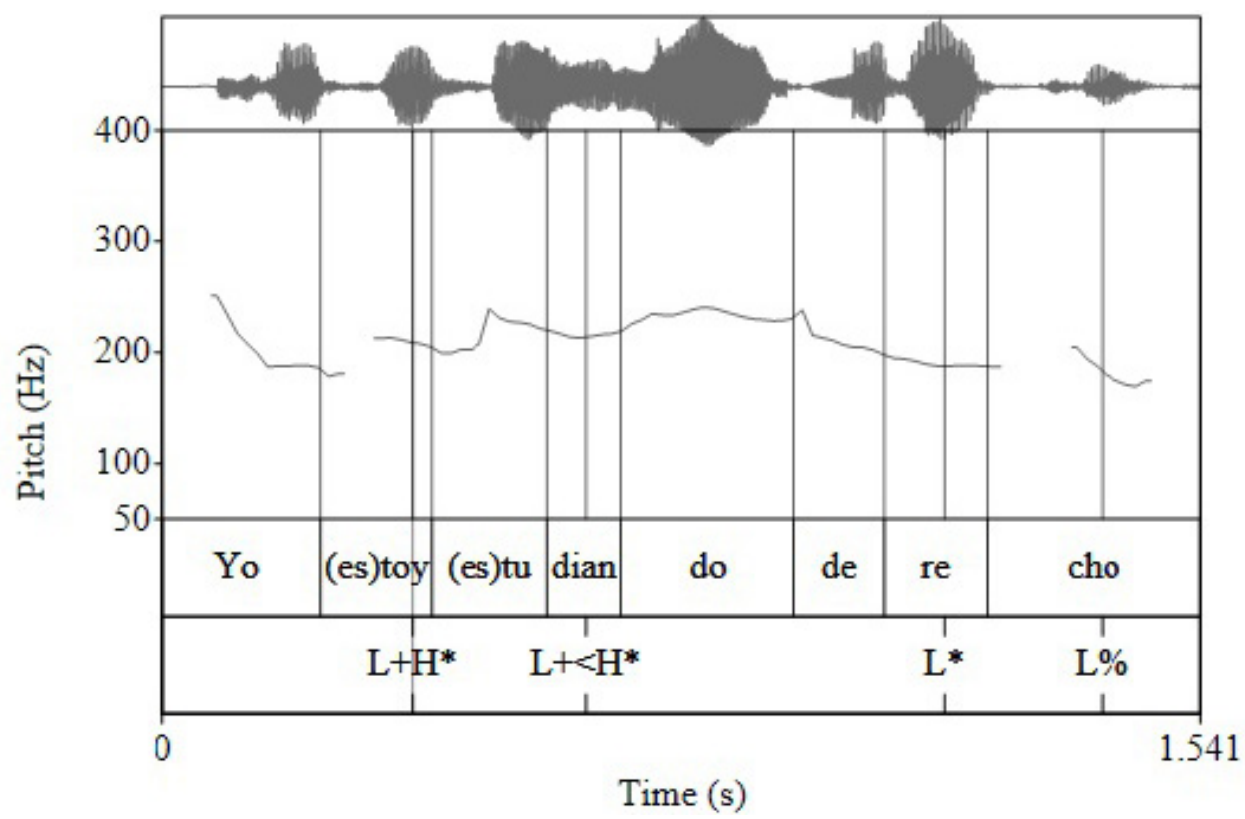

Figure 2: Waveform and $\mathrm{f}_{0}$ curve of the declarative sentence La gallega y la asturiana ya no son iguales ('The Galician and the Asturian [bagpipes] are not the same') uttered by the Amestáu interviewer.

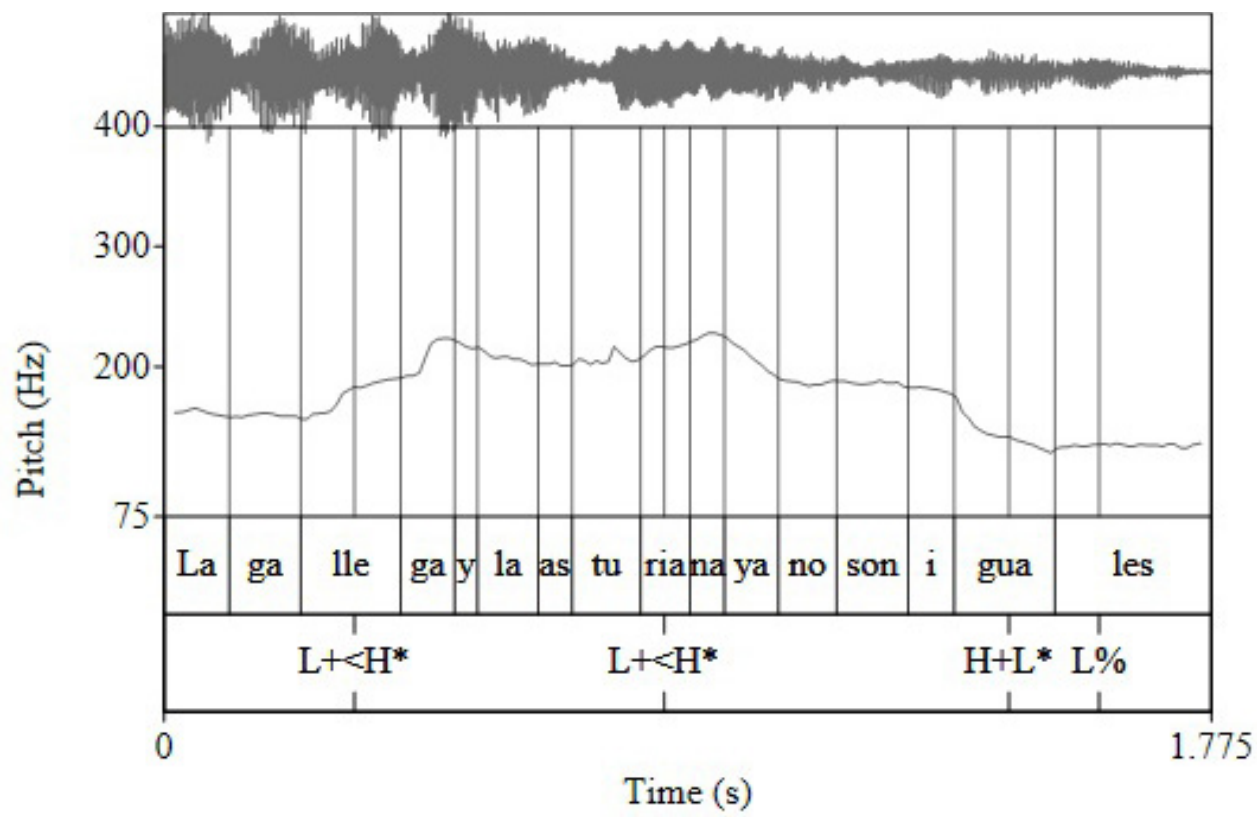

the falling configurations of Asturian are present in Amestáu and Asturian Spanish. Figure 5 illustrates a final falling contour in Asturian Spanish.

As Figure 6 shows, all the relocated speakers that were interviewed for this experiment showed higher rates of falling final contours in absolute interrogatives when they were in conversation with the Amestáu interlocutor.
All speakers taken together, the differences in percentages of occurrence of falling nuclear contours with an Amestáu or an Andalusian interlocutor are statistically significant $\left(\chi^{2}=7.206, p<.007\right)$. Individually, the differences are only significant for Speaker $3\left(\chi^{2}=6.930\right.$, $p<.008)$. The numbers and percentages are shown in Table 6. 
Table 5: Frequency of $\mathrm{H}+\mathrm{L} * \mathrm{~L} \%$ in declarative utterances by the relocated Andalusian speakers.

\begin{tabular}{|c|c|c|c|c|}
\hline \multirow{2}{*}{} & \multicolumn{2}{|c|}{ Amestáu interlocutor } & \multicolumn{2}{c|}{ Andalusian interlocutor } \\
\cline { 2 - 5 } & $\boldsymbol{N}$ & Freq. $\mathbf{H}+\mathbf{L}^{*} \mathbf{L} \%$ & $\boldsymbol{N}$ & Freq. H+L* L\% \\
\hline Speaker 1 & 23 & $39.1 \%$ & 17 & $29.4 \%$ \\
\hline Speaker 2 & 18 & $33.3 \%$ & 21 & $23.8 \%$ \\
\hline Speaker 3 & 29 & $75.9 \%$ & 20 & $40 \%$ \\
\hline Speaker 4 & 18 & $50 \%$ & 29 & $41.4 \%$ \\
\hline
\end{tabular}

Figure 3: Frequency of $\mathrm{H}+\mathrm{L} * \mathrm{~L} \%$ in declarative utterances by the relocated Andalusian speakers with respect to the interlocutor.

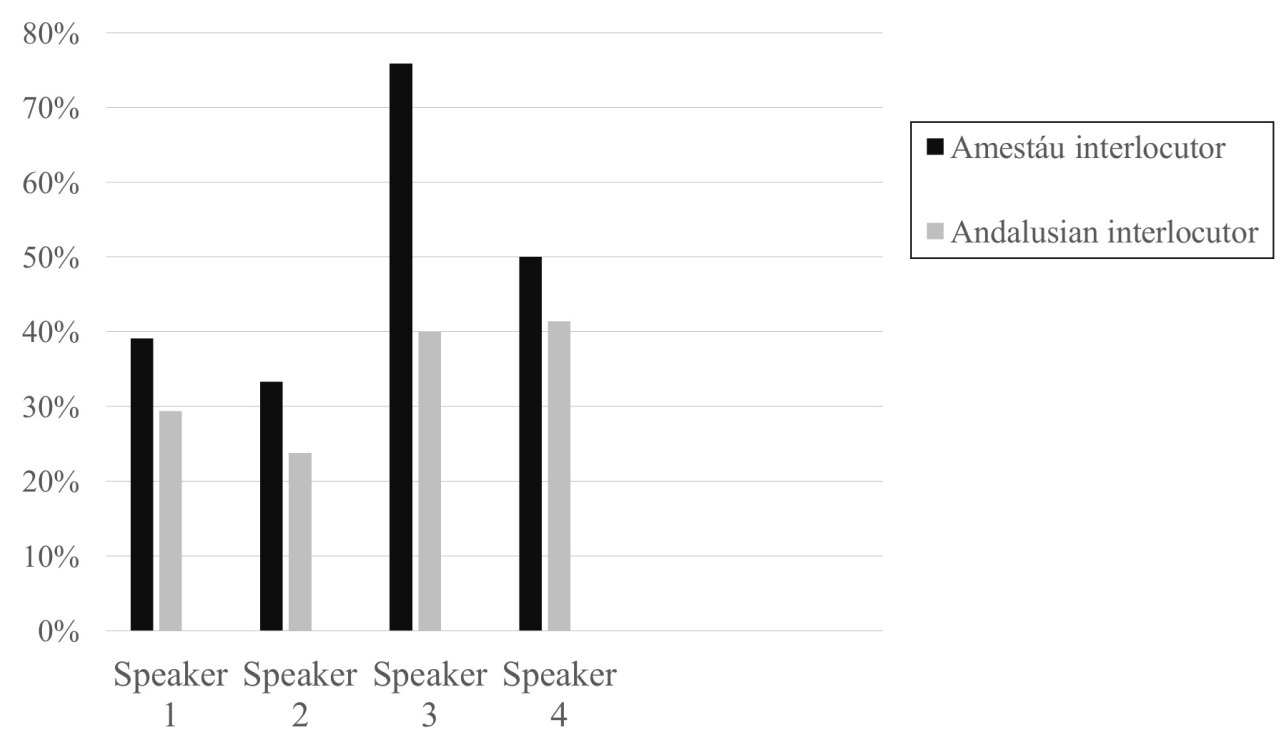

\subsection{Wh-interrogatives}

No previous study has described the configuration of wh-interrogatives in any of the varieties spoken in Asturias. Our corpus of Asturian Spanish and Amestáu points out a falling nuclear accent followed by a low valley $(\mathrm{H}+\mathrm{L} * \mathrm{~L} \%)$ as the most frequent configuration $(51 \%){ }^{4}$ As regards Western Andalusian Spanish configuration, Henriksen and García-Amaya (2012) report two different configurations: $\mathrm{H}+\mathrm{L} * \mathrm{~L} \%$ and $\mathrm{L}+{ }_{i} \mathrm{H}^{*} \mathrm{~L} \%$. Since Amestáu/Asturian Spanish and Western Andalusian share the falling configuration $\mathrm{H}+\mathrm{L} * \mathrm{~L} \%$, it would not be possible to talk about convergence or accommodation of the relocated Andalusian speakers to the Amestáu interlocutor. Since the main difference between Andalusian Spanish and Amestáu/Asturian Spanish is the presence vs. absence of the final circumflex contour $\left(\mathrm{L}+{ }_{i} \mathrm{H}^{*} \mathrm{~L} \%\right)$, the only indicator of possible convergence or accommodation would be a decrease in the use of the Andalusian cir- cumflex accent $\mathrm{L}+{ }_{i} \mathrm{H}^{*} \mathrm{~L} \%$ by relocated Andalusian speakers. However, measuring accommodation in terms of loss of native features - rather than adoption of new ones-implies a different metric to the one used for declaratives and absolute interrogatives in this article. For the sake of coherence in the investigation, we have preferred not to include wh-interrogatives in the analysis.

\section{DISCUSSION}

The results of our study confirm that all speakers, in different degrees, showed a convergent accommodating behaviour after living in Asturias for a short period of time. Therefore, we can conclude that Asturian prosodic features, such as the falling nuclear contour in declarative and absolute interrogative utterances, are observed in relocated Andalusian Spanish speakers. Moreover, the different percentages of occurrence of these contours con-

\footnotetext{
${ }^{4}$ A low nuclear accent followed by a low boundary tone ( $\left.\mathrm{L} * \mathrm{~L} \%\right)$ and a falling nuclear accent followed by a downstepped rising boundary tone $\left(\mathrm{H}+\mathrm{L}^{*} ! \mathrm{H} \%\right)$ were also found, albeit less frequently $(26 \%$ and $23 \%$, respectively).
} 
Figure 4: Waveform and $f_{0}$ curve of the absolute interrogative ¿Te gustaria tener hijos? ('Would you like to have children?') uttered by a control Andalusian Spanish speaker.

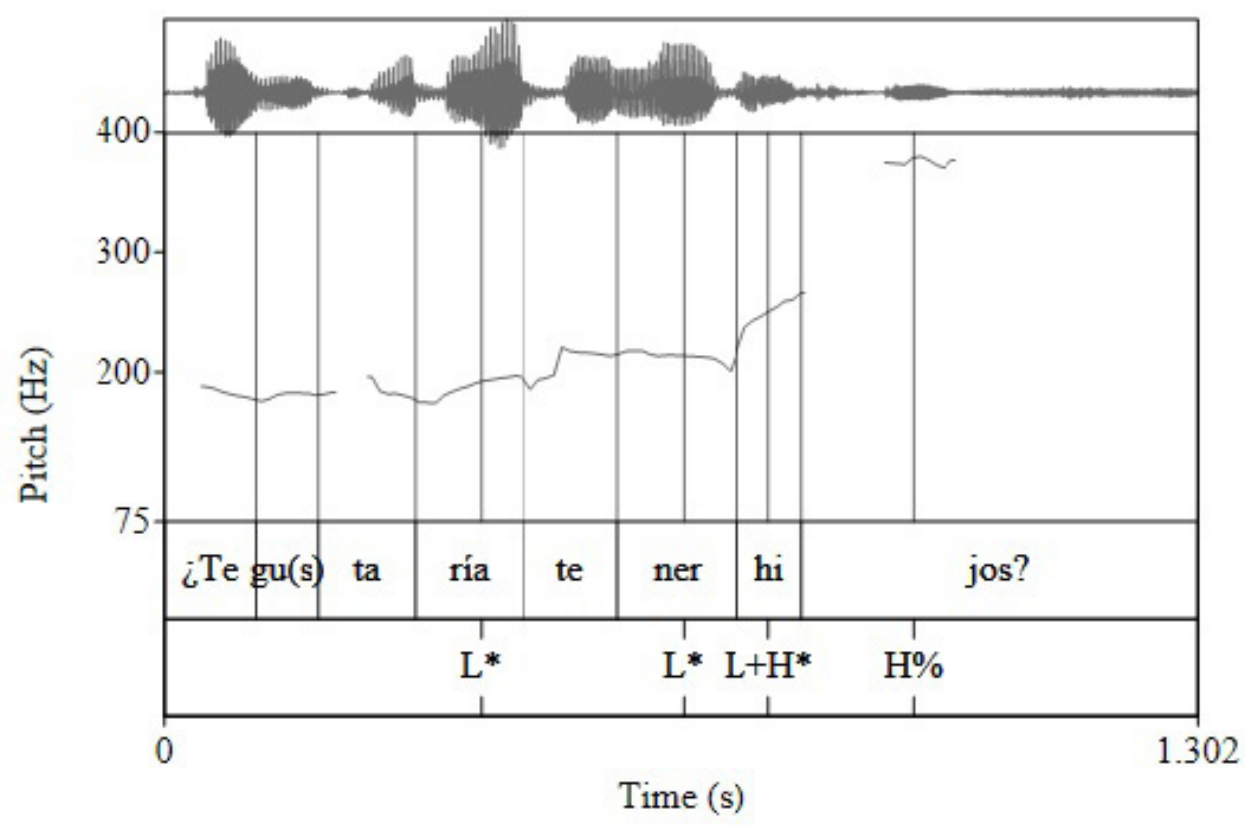

Figure 5: Waveform and $f_{0}$ curve of the absolute interrogative ¿Tú estuviste en Italia? ('Have you ever been to Italy?') uttered by the Asturian Spanish speaker.

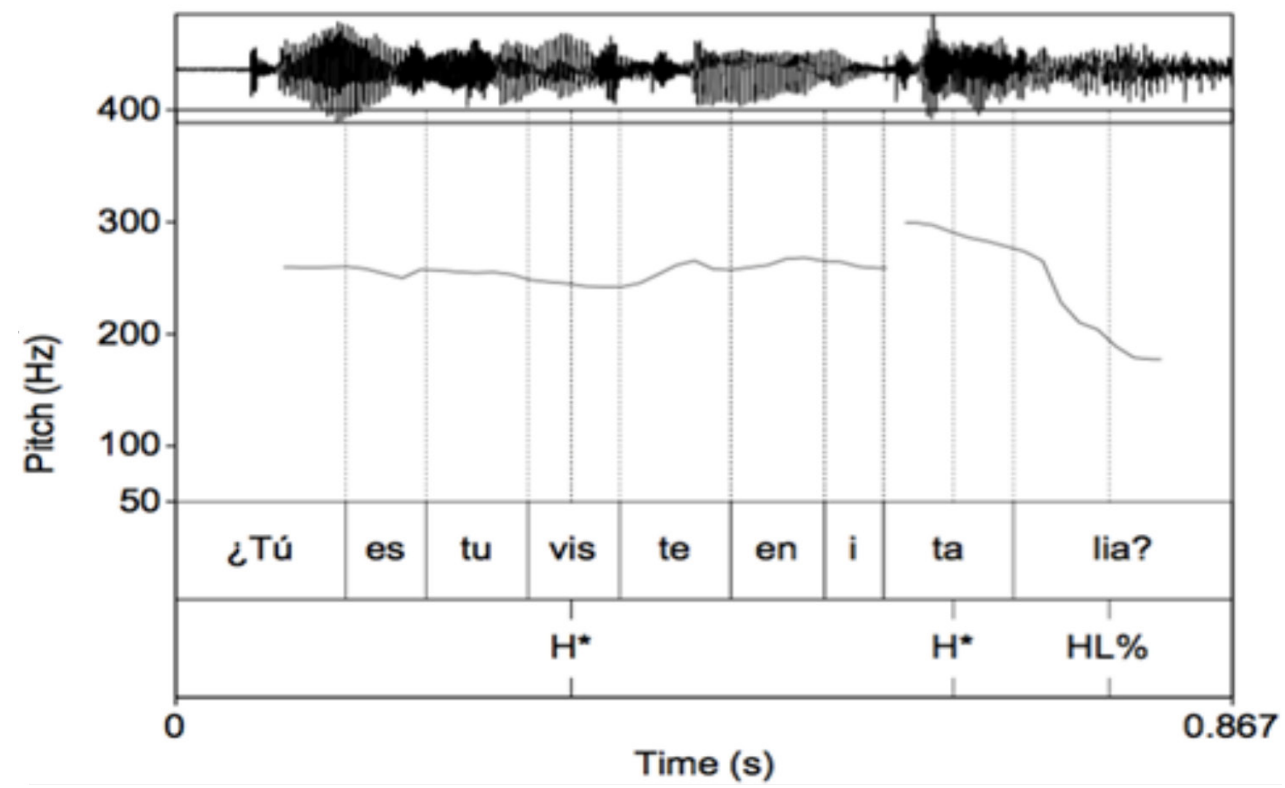

firm the key role that the interlocutor plays in the process of accommodation, as there is a general tendency for these features to appear more frequently when the participants are engaging in conversation with the Amestáu interlocutor. ${ }^{5}$
The sociolinguistic interview of the relocated speakers carried out by the Andalusian interlocutor provided enough information for the classification of the relocated speakers, following the criteria in Auer et al. (1998). The parameters include the ties and the attitude that the speak-

\footnotetext{
5 It must be acknowledged that the presence of Amestáu or Asturian Spanish nuclear contours with the Andalusian interlocutor could be triggered by the topic of the conversation, related to life in Asturias, as well as to the fact that the interview with the Andalusian interlocutor took place after the one with the Amestáu interlocutor. Whether a more neutral topic and a reverse order of interviews might have led to lower percentages of Asturian configurations must be left open. We thank an anonymous reviewer for pointing this out.
} 
Figure 6: Frequency of $\mathrm{H}+\mathrm{L} * \mathrm{~L} \%$ and $\mathrm{H}^{*}(\mathrm{H}) \mathrm{L} \%$ in absolute interrogatives produced by the relocated Andalusian speakers with respect to the interlocutor.

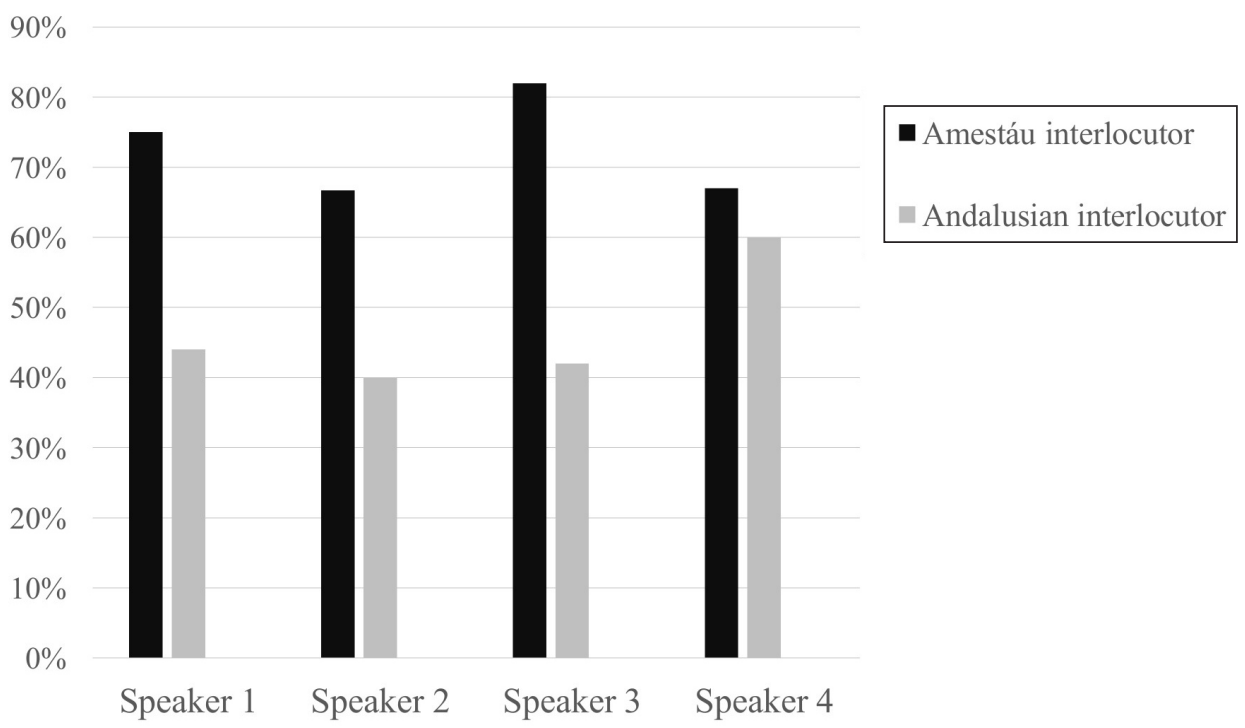

Table 6: Frequency of $\mathrm{H}+\mathrm{L}^{*} \mathrm{~L} \%$ and $\mathrm{H}^{*}(\mathrm{H}) \mathrm{L} \%$ in absolute interrogatives produced by the relocated Andalusian speakers.

\begin{tabular}{|c|c|c|c|c|}
\hline \multirow{2}{*}{} & \multicolumn{2}{|c|}{ Amestáu interlocutor } & \multicolumn{2}{c|}{ Andalusian interlocutor } \\
\cline { 2 - 5 } & $\boldsymbol{N}$ & $\boldsymbol{N}$ & $\boldsymbol{N}$ & $\%$ \\
\hline Speaker 1 & 8 & $75 \%$ & 9 & $44 \%$ \\
\hline Speaker 2 & 9 & $66.70 \%$ & 10 & $40 \%$ \\
\hline Speaker 3 & 22 & $82 \%$ & 19 & $42 \%$ \\
\hline Speaker 4 & 12 & $67 \%$ & 10 & $60 \%$ \\
\hline
\end{tabular}

ers have with the local community (cf. Babel, 2010), and the degree of satisfaction with their personal situation in Asturias. Speakers 1 and 2 both had boyfriends who were either Andalusian or half Andalusian, and they were unsatisfied with their situation, stating explicitly that they wanted to go back to Andalusia as soon as possible. They both described Asturian people as cold, introvert, or less enjoyable than Andalusians, and they deemed weather in Asturias unbearable and the main cause for them to want to get away from Asturias. In addition, they were both unemployed and their social networks in Asturias were small and mostly formed by other relocated speakers. They did not have intense contact with locals and, therefore, they were less exposed to the features of Amestáu or Asturian Spanish. We can assume that infrequent exposure leads to a worse perception of prosodic aspects that are novel or different from the native language or dialect, which in turn derives in a more unlikely adoption of such features.

The opposite situation was found in Speaker 3, who was a student at the University of Oviedo, and Speaker 4, who was employed. They had contact with Asturians on a daily basis, and in fact they reported their closest group of friends to be Asturian. As expected, the analysis shows that, during the entire recording including the interview with the Amestáu and the Andalusian interlocutors together, these speakers were the ones showing the highest rates of falling nuclear configurations in their declarative and interrogative utterances.

It is interesting to point out that a negative association is observed between the attitude towards the Asturian community and the attitude towards the Andalusian community. Thus, Speakers 1 and 2, who offered a rather negative description of the Asturian community, praised Andalusian lifestyle; and, vice versa, Speakers 3 and 4, who focused on positive aspects of Asturias, such as landscape, gastronomy, job opportunities, and Asturian culture, were the ones who often criticized the Andalusian population characterizing them as narrow-minded, among other features.

All the criteria mentioned above allow us to describe Speakers 3 and 4 as the most socially integrated in Astu- 
rias, and Speakers 1 and 2 as the least socially integrated. Taking into account the results described in Section 3, an association is observed between the degree of social integration and the percentage of Amestáu or Asturian Spanish features in these speakers. Speakers 3 and 4 feel more comfortable in Asturias, have a positive attitude towards Asturian culture, larger social networks and praise less enthusiastically Andalusian traditions. They are the ones showing a higher degree of presence of Amestáu or Asturian Spanish intonational features when engaging in conversation with an Andalusian or an Amestáu interlocutor. These speakers have an overall frequency of occurrence of Amestáu or Asturian Spanish nuclear configurations in declarative and interrogative sentences of $59.98 \%$ and $54.6 \%$, respectively, taking into account their performance with both the Amestáu and Andalusian interlocutors. On the other hand, Speakers 1 and 2, who do not show this positive attitude, present a smaller presence of such features: $46.88 \%$ and $40.95 \%$ of final falling contours in declarative and absolute interrogative utterances, respectively. The difference between Speaker 1 and Speaker 2 is not statistically significant $\left(\chi^{2}=.466\right.$, $p=.495)$, nor the difference between Speakers 3 and 4 $\left(\chi^{2}=2.109, p=.146\right)$, and the difference between Speakers 1 and 2 and Speaker 3 is significant $\left(\chi^{2}=5.660, p=.017\right.$ and $\chi^{2}=9.564, p=.002$, respectively). If a comparison is made of these two groups, that is, the less integrated speakers (Speakers 1-2) versus the more integrated ones (Speakers 3-4), the difference is significant $\left(\chi^{2}=8.655\right.$, $p=.003)$. The division in two groups formed by Speakers 1-2 on the one hand and Speakers 3-4 on the other hand is not completely warranted, due to the lack of statistical significance of the difference between Speakers 1-2 and Speaker 4: $\chi^{2}=.891, p=.345$ and $\chi^{2}=2.694, p=.101$, respectively). We can thus (tentatively) conclude that an association between the degree of social integration and the degree of presence of intonation features of Amestáu or Asturian Spanish can be observed.

A final point is in order regarding the differences in frequency of adoption of intonational features between declarative and absolute interrogative utterances. When addressing an Amestáu interlocutor, relocated Andalusians use the Amestáu/Asturian Spanish H+L* L\% nuclear contour in $41.6 \%$ of the total number of nuclear contours in declarative sentences. In absolute interrogatives, relocated Andalusians use the Amestáu/Asturian Spanish $\mathrm{H}+\mathrm{L} * \mathrm{~L} \%$ nuclear contour $59.59 \%$ of the total number of nuclear contours. We resort to the notion of salience to explain variability in this phenomenon of linguistic transfer. Following Auer et al. (1998), Flege (1995), Fridland et al. (2004), Graff et al. (1986), MacLeod (2012), Schirmunski (1930), Trudgill (1986), and van Bezooijen and Gooskens (1999), among others, we assume that features of language or dialect that are salient to native speakers of another language or dialect are more easily noticed and picked up than nonsalient features (cf. the role of salience in Flege's 1995 model of acquisition). We assume that prosodic salience is based on the relative difference between two prosodic configurations. To the native ears of the speakers of a language or dialect, a prosodic configuration of another language or dialect that is nonexistent or significantly different from their native language/dialect will be more salient than a prosodic configuration that is only a marginally different variant of their native configuration. Hence, the hypothesis would be that features that are prosodically salient are more easily adopted than others, the same way that salient segmental features are more easily acquired than nonsalient or less salient features (see Flege, 1995). Thus, the fact that some prosodic features (such as absolute interrogative contours) are more likely to be acquired than others (such as declarative prosodic configurations) can be explained by the effect that linguistic silence has on dialect convergence.

If we take into account the configuration for absolute interrogatives and declaratives in Andalusian Spanish compared to Amestáu and Asturian Spanish, we can hypothesize that the prosodic configuration of absolute interrogatives in Amestáu or Asturian Spanish is perceptually more salient to Andalusian speakers than the contours found in declaratives. Absolute interrogatives of Amestáu and Asturian Spanish end in the falling nuclear configurations $\mathrm{H}+\mathrm{L} * \mathrm{~L} \%$ or $\mathrm{H}^{*}(\mathrm{H}) \mathrm{L} \%$, whereas in Western Andalusian they end in final rising configurations, $\mathrm{L}^{*} \mathrm{H} \%$ or $\mathrm{L}+\mathrm{H}^{*} \mathrm{H} \%$. Hence, the difference between the nuclear contours of Amestáu or Asturian Spanish absolute interrogatives and those of Andalusian Spanish lies both in the nuclear accent and the boundary tone. ${ }^{6}$ On the other hand, in declarative utterances the difference between varieties is smaller. In Western Andalusian Spanish the final contour is L* L\%, whereas in Amestáu or Asturian Spanish it is $\mathrm{H}+\mathrm{L} * \mathrm{~L} \%$. The difference lies only in the nuclear pitch accent, as the boundary tone is the same, and the difference is limited to the presence versus absence of a leading $\mathrm{H}$ tone, as the starred tone is $\mathrm{L}^{*}$ in both cases. Thus, absolute interrogatives would be more salient than declarative sentences for Andalusian Spanish speakers, and the higher degree of salience could explain the relatively higher degree of adoption of nuclear contours of absolute interrogatives by relocated Andalusian speakers.

\section{CONCLUSIONS}

We observed that relocated Andalusian speakers changed their native nuclear contours in declarative and absolute interrogative sentences after living in Asturias for a short period of time ( 1 to 5 years). We have success-

\footnotetext{
${ }^{6}$ There could be additional salient features of absolute interrogatives in Amestáu and Asturian Spanish, such as a higher pitch register in prenuclear accents and a wider pitch range in the nuclear region, mentioned in 3.2. But this possibility would have to be confirmed through further empirical research.
} 
fully identified the prosodic features that these speakers adopt. In declarative sentences, the falling pitch movement is delayed as late as the nuclear accent of the sentence, as opposed to the Andalusian configuration, where the nuclear accent is already a low valley. As regards absolute interrogatives, falling final contours are even more frequent in the production of these speakers, in whose native variety of Spanish the predominant configuration is the complete opposite, a rising tone.

We took into consideration to what extent social factors were intervening in the degree of social accommodation. As expected, we found that the interlocutor has a key role in this process, as the relocated speakers modified their speech patterns by means of incorporating Asturian features more frequently when they were in conversation with the Amestáu interlocutor. Moreover, an association was observed between social integration and accommodation, as those speakers who were better socially integrated, and therefore are more constantly exposed to the varieties spoken in Asturias, were the ones displaying higher levels of accommodation in both conversation stages.

Finally, our results of the analysis of the production of these speakers indicate that the relocated Andalusian speakers show a higher presence of Amestáu or Asturian Spanish nuclear contours in absolute interrogative utterances than in declarative utterances. Our proposed explanation for this difference is that phonetic salience also plays a role in determining which features are more easily affected by linguistic transfer. The falling nuclear contours in absolute interrogatives typical of Amestáu and Asturian Spanish $\left(\mathrm{H}+\mathrm{L}^{*} \mathrm{~L} \%\right.$ and $\left.\mathrm{H}^{*}(\mathrm{H}) \mathrm{L} \%\right)$ are salient to the Andalusian speakers, with mostly rising configurations $\left(\mathrm{L} * / \mathrm{L}+\mathrm{H}^{*} \mathrm{H} \%\right)$. Both the nuclear accent and the boundary tone of Amestáu and Asturian Spanish are different to the Andalusian variety. The difference between the falling nuclear accents in declaratives typical of Amestáu $\left(\mathrm{H}+\mathrm{L}^{*} \mathrm{~L} \%\right)$ and Andalusian $\left(\mathrm{L}^{*} \mathrm{~L} \%\right)$ is not so salient, as only the nuclear accent is different and the contour is falling in both cases. A plausible explanation would thus be that most salient features are acquired more easily. In conclusion, then, our study provides support to the idea that accommodation is modulated both by linguistic factors (native variety of the interlocutor, salience of linguistic features) and social factors (degree of social integration).

\section{ACKNOWLEDGMENTS}

We are grateful to two anonymous reviewers, whose comments and suggestions have helped improve the paper substantially. A previous version of this paper was presented at the conference Tone and Intonation in Europe 2016 (University of Kent, September 1-3, 2016), and we want to thank the audience there for their feedback. This work has been partially funded by the Basque Government (IT-76913 and PIC 168/15), the University of the Basque Country (UFI 11/14), and the Spanish Ministry of Economy and Competitiveness (FFI2016-80021-P).

\section{REFERENCES}

Alvar, M. (1959). Atlas lingüistico y etnográfico de Andalucía. Universidad de Granada. Granada: CSIC

Alvarellos Pedrero, M., Muñiz Cachón, C., Díaz Gómez, L., \& González Rodríguez, R. (2011). La entonación en las variedades lingüísticas de Asturias: Estudio contrastivo. Revista Internacional de Lingüística Iberoamericana, 9, 111-120.

Auer, P., Barden, B., \& Grosskopf, B. (1998). Subjective and objective parameters determining 'salience' in long-term dialect accommodation. Journal of Sociolinguistics, 2(2), 163-187. https://doi.org/10.1111/1467-9481.00039

Babel, M. (2010). Dialect divergence and convergence in New Zealand English. Language in Society, 39(4), 437-456. https://doi. org/10.1017/S0047404510000400

Beckman, M. E., Díaz-Campos, M., McGory, J. T., \& Morgan, T. A. (2002). Intonation across Spanish, in the Tones and Break Indices framework. Probus, 14(1), 9-36. https://doi.org/10.1515/ prbs.2002.008

Beckman M. E., \& Pierrehumbert, J. B. (1986). Intonational structure in Japanese and English. Phonology Yearbook, 3, 255-309. https://doi.org/10.1017/S095267570000066X

Caja, G. S. (1977). Unidades fonológicas vocálicas en andaluz oriental. Revista Española de Lingüística, 7, 1-24.

Canellada, M. J. (1984). Notas de entonación asturiana. Lletres Asturianes, 10, 23-27.

Carbonero, P., Álvarez, J. L., Casas, J., \& Gutiérrez, I. M. (1992). El habla de Jerez. Estudio sociolingüistico. Jerez: Ayuntamiento de Jerez.

Colantoni, L., \& Gurlekian, J. (2004). Convergence and intonation: Historical evidence from Buenos Aires Spanish. Bilingualism: Language and Cognition, 7(2), 107-119. https://doi. org/10.1017/S1366728904001488

Cuevas Alonso, M., \& López Bobo, M. J. (2010). Alineamiento, acento y tiempo en asturiano central. Lingüistica Española Actual, 32, 35-64.

Cuevas Alonso, M., López Bobo, M. J., Arias-Cachero Cabal, Á., \& Bleorţu, C. (2012). El patrón entonativo norteño. Evidencia del español hablado en Galicia, Asturias y Cantabria. Language and Literature. European Landmarks of Identity, 11(2), 358-364.

d'Andrés Díaz, R. (1998). Algunas notas sobre bilingüismo y contacto de lenguas en Asturias. In A. M. Cano González (Ed.), Patronymica Románica 11, Dictionnaire historique des nomes de famille romans (IX) (pp. 161-174). Tübingen: Max Niemeyer. https://doi.org/10.1515/9783110909449.161

De Looze, C., Scherer, S., Vaughan, B., \& Campbell, N. (2014). Investigating automatic measurements of prosodic accommodation and its dynamics in social interaction. Speech Communication, 58, 11-34. https://doi.org/10.1016/j.specom.2013.10.002

Díaz Gómez. L., Muñiz Cachón, C., López Bobo, M. J., González Rodríguez, R., \& Cuevas Alonso, M. (2007). La entonación en dos zonas rurales del centro de Asturias. Archivum: Revista de la Facultad de Filología, 56, 263-289.

Elordieta, G. (2003). The Spanish intonation of speakers of a Basque pitch-accent dialect. Catalan Journal of Linguistics, 2, 67-95.

Elordieta, G. (2006). Spanish pitch accent alignment by Northern Bizkaian Basque speakers. In B. Fernández \& I. Laka (Eds.), Andolin Gogoan. Essays in honour of Profesor Eguzkitza (pp. 269-290). Bilbao: Servicio Editorial de la Universidad del País Vasco.

Elordieta, G., \& Calleja, N. (2005). Microvariation in accentual alignment in Basque Spanish. In Language and Speech, 48(4), 397-439. https://doi.org/10.1177/00238309050480040401

Elordieta, G., \& Irurtzun, A. (2012). Estudio comparativo de alineamiento tonal en el castellano de Bilbao. In B. Camus-Bergareche \& S. Gómez-Seibane (Eds.), El Castellano del País Vasco (pp. 119137). Bilbao: University of the Basque Country UPV/EHU.

Elordieta, G., \& Irurtzun, A. (2016). Pitch accent tonal alignment in declarative sentences in the Spanish of the Basque Country: A 
language contact study. In M. E. Armstrong, N. Henriksen, \& M. del M. Vanrell (Eds.), Intonational grammar in Ibero-Romance: Approaches across linguistic subfields (pp. 25-44). Amsterdam: John Benjamins. https://doi.org/10.1075/ihll.6.02elo

Elordieta, G., \& Romera, M. (in press). The influence of social factors on the prosody of Spanish in contact with Basque. In M. Bouzouita, R. Enghels, \& C. Vanderschueren (Eds.), Different perspectives on convergence and divergence in Ibero-Romance: Language contact and contrasting national varieties. Amsterdam: John Benjamins.

Estebas Vilaplana, E., \& Prieto Vives, P. (2008). La notación prosódica del español: Una revisión del Sp_ToBI. Estudios de Fonética Experimental, 17, 263-283.

Face, T. L. (2008). The intonation of Castilian Spanish declaratives and absolute interrogatives. Munich: Lincom Europa.

Flege, J. E. (1995). Second language speech learning: Theory, findings, and problems. In W. Strange (Ed.), Speech perception and linguistic experience: Issues in cross-language research (pp. 233-277). Timonium, MD: York.

Fridland, V., Bartlett, K., \& Kreuz, R. (2004). Do you hear what I hear? Experimental measurement of the perceptual salience of acoustically manipulated vowel variants by Southern speakers in Memphis, TN. Language Variation and Change, 16, 1-16. https://doi.org/10.1017/S0954394504161012

García Mouton, P. (1992). El atlas lingüístico y etnográfico de Andalucía. Hombres y mujeres. Campo y ciudad. Iker 7: Actas del Congreso Internacional de Dialectología (pp. 667-685). Bilbao: Euskaltzandia.

García-Amaya, L. J. (2008). Variable norms in the production of $/ \theta /$ in Jerez de la Frontera, Spain. In J. F. Siegel, T. C. Nagle, \& J. Auger (Eds.), IUWPL7: Gender in language: Classic questions, new contexts (pp. 49-71). Bloomington: IUCL Publications.

Gil Fernández, J. (2000). Panorama de la fonología española actual. Madrid: Arco/Libros.

Giles, H. (1973). Accent mobility: A model and some data. Anthropological Linguistics, 15(2), 87-109.

Giles, H., Coupland, N., \& Coupland, I. (Eds.). (1991). Contexts of accommodation: Developments in applied sociolinguistics. Cambridge: Cambridge University Press. https://doi. org/10.1017/CBO9780511663673

Giles H., \& Ogay, T. (2007). Communication accommodation theory. In B. B. Whaley and W. Samter (Eds). Explaining communication: Contemporary theories and exemplars (pp. 325-344). Mahwah, NJ: Lawrence Erlbaum.

Graff, D., Labov, W., \& Harris, W.A. (1986). Testing listeners' reactions to phonological markers of ethnic identity: A new method for sociolinguistic research. In D. Sankoff (Ed.), Diversity and diachrony: Current issues in linguist theory 53 (pp. 45-58). Amsterdam: John Benjamins. https://doi.org/10.1075/ cilt.53.07gra

Henriksen, N., \& García-Amaya, L. (2012). Transcription of intonation of Jerezano Andalusian. Estudios de Fonética Experimental, 21, 109-162.

Hernández-Campoy, J. M. (2010). Dialect contact and accommodation in a standard context. Sociolinguistic Studies, 4(1), 201226. https://doi.org/10.1558/sols.v4i1.201

Hualde, J. I. (2005). The sounds of Spanish. Cambridge: Cambridge University Press.

Hualde, J. I. (2013). Los sonidos del español (Spanish language ed.). Cambridge: Cambridge University Press. https://doi. org/10.1017/CBO9780511719943

Hualde, J. I., \& Prieto, P. (2015). Intonational variation in Spanish: European and American varieties. In S. Frota \& P. Prieto (Eds.), Intonation in Romance (pp. 350-391). Oxford: Oxford University Press. https://doi.org/10.1093/acprof:o so/9780199685332.003.0010

Ladd, D. R. (2008). Intonational phonology. Cambridge: Cambridge University Press.

Lewis, M. P., Simons, G. F., \& Fennig, C. D. (Eds.). (2015). Ethnologue: Languages of the World, eighteenth edition. Dallas, Texas: SIL International. [Online version: http://www.ethnologue. com].
López Bobo, M. J., Cuevas Alonso, M., Díaz Gómez, M., \& Viejo Lucio-Villegas, M. (2008a). Análisis contrastivo de la prosodia del asturiano central y occidental. Language design: Journal of theoretical and experimental linguistics. Special issue 2: Experimental prosody, 267-282.

López Bobo, M. J., Cuevas Alonso, M., Díaz Gómez, M., \& Viejo Lucio-Villegas, M. (2008b). Prosodia del occidente de Asturias: Secuencias con estructura Sujeto-Verbo-Objeto. Archivum, LVII, 1-32.

López Bobo, M. J., González Rodríguez, R., Cuevas Alonso, M., Díaz Gómez, L., \& Muñiz Cachón, C. (2005). Rasgos prosódicos del centro de Asturias: Comparación Oviedo-Mieres. Estudios de Fonética Experimental, 14, 169-199.

Llera Ramo, F. J. (1994). Los asturianos y la lengua asturiana: Estudio sociolingüístico para Asturias-1991. Uviéu: Serviciu de Publicaciones del Principáu d'Asturies.

Llera Ramo, F. J., \& San Martín Antuña, P. (2002). II Estudio sociolingüistico de Asturias. Uviéu: Academia de la Llingua Asturiana.

MacLeod, B. (2012). The effect of perceptual salience on cross-dialectal phonetic convergence in Spanish (Doctoral dissertation). University of Toronto.

Mennen, I. (2004). Bi-directional interference in the intonation of Dutch speakers of Greek. Journal of Phonetics, 32(4), 543563. https://doi.org/10.1016/j.wocn.2004.02.002

Mennen, I. (2015). Beyond segments: Towards a L2 intonation learning theory. In E. Delais-Roussarie, M. Avanzi, \& S. Herment (Eds.), Prosody and language in contact (pp. 171-188). Berlin: Springer. https://doi.org/10.1007/978-3-662-45168-7_9

Mondéjar, J. (2001). Dialectología andaluza. Universidad de Málaga.

Muntendam, A., \& Torreira, F. (2016). Focus and prosody in Spanish and Quechua. In M. Armstrong, N. Henriksen, \& M. del M. Vanrell (Eds.), Intonational grammar in Ibero-Romance: Approaches across linguistic subfields (pp. 69-90). Amsterdam: John Benjamins. https://doi.org/10.1075/ihll.6.04mun

Muñiz Cachón, C. (2002-2003). Rasgos fónicos del español hablando en Asturias. Archivum: Revista de la Facultad de Filología, 52-53, 323-349.

Muñiz Cachón, C. (2013). La entonación asturiana n’el marcu de les llingües romániques: Los atles prosódicos. Lletres Asturianes, 109, 11-29.

Muñiz Cachón, C., \& Alvarellos Pedrero, M. (2008). Una nota peculiar en la prosodia asturiana: La entonación oriental. In A. Turculet (Ed.), La variation diatopique de l'intonation dans le domain roumain et roman (pp. 103-122). Iaşi: Editura Universitatii "Alexandru Ioan Cuza".

Muñiz Cachón, C., González Rodríguez, R. Díaz Gómez, L., \& Alvarellos Pedrero, M. (2006-2007-2008). Prosodia gallegoasturiana en enunciaos SVO. Revista de Filoloxía asturiana, 6 , 7, 8, 335-349.

Narbona, A., Cano, R., \& Morillo, R. (1998). El español hablado en Andalucía. Barcelona: Ariel.

Navarro Tomás, T. (1991). Manual de pronunciación española (25. ${ }^{\mathrm{a}}$ ed.). Madrid: Consejo Superior de Investigaciones Científicas.

O'Rourke, N. (2005). Intonation and language contact: A case study of two varieties of Peruvian Spanish (Doctoral dissertation). University of Illinois at Urbana-Champaign.

Pardo, J. S. (2006). On phonetic convergence during conversational interaction. Journal of the Acoustical Society of America, 119(4), 2382-2393. https://doi.org/10.1121/1.2178720

Pardo, J. S. (2013). Measuring phonetic convergence in speech production. Frontiers in Psychology, 4, 559. https://doi. org/10.3389/fpsyg.2013.00559

Pierrehumbert, J. B. (1980). The phonology and phonetics of English intonation (Doctoral dissertation). Massachusetts Institute of Technology, Cambridge, MA.

Pierrehumbert, J. B., \& Beckman, M. E. (1988). Japanese tone structure (Linguistic Inquiry Monograph 15). Cambridge, MA: MIT Press.

Prieto, P., \& Roseano, P. (Eds). (2010). Transcription of intonation of the Spanish language. Munich: Lincom Europa. 
Romano, A., Lai, J. P., \& Roullet, S. (2005). La méthodologie AMPER. Géolinguistique, 3-Hors Série, Projet AMPER, 1-5.

Romera, M., \& Elordieta, G. (2013). Prosodic accommodation in language contact: Spanish intonation in Majorca. International Journal of the Sociology of Language, 221, 127-151. https:// doi.org/10.1515/ijsl-2013-0026

Schirmunski, V. (1930). Sprachgeschichte und Siedelungsmundarten. Germanisch-Romanische Monatsschrift, 18, 113-122, 171-88.

Simonet, M. (2008). Language contact in Majorca: An experimental sociophonetic approach (Doctoral dissertation). University of Illinois at Urbana-Champaign.

Simonet, M. (2011). Intonational convergence in language contact: Utterance-final F0 contours in Catalan-Spanish bilinguals.
Journal of the International Phonetic Association, 41, 157-184. https://doi.org/10.1017/S0025100311000120

Sociedad Asturiana de Estudios Económicos e Industriales (2017). Movimientos migratorios en Asturias 2015. Gobierno del Principado de Asturias.

Trudgill, P. (1986). Dialect contact, dialectology and sociolinguistics. In K. Bolton and H. Kwok (Eds.), Sociolinguistics today: International perspectives (pp. 71-79). London: Routledge.

van Bezooijen, R., \& Gooskens, C. (1999). Identification of language varieties: The contribution of different linguistic levels. Journal of Language and Social Psychology, 18(1), 31-48. https://doi.org/10.1177/0261927X99018001003

Zamora Vicente, A. (1967). Dialectología española. Madrid: Gredos. 